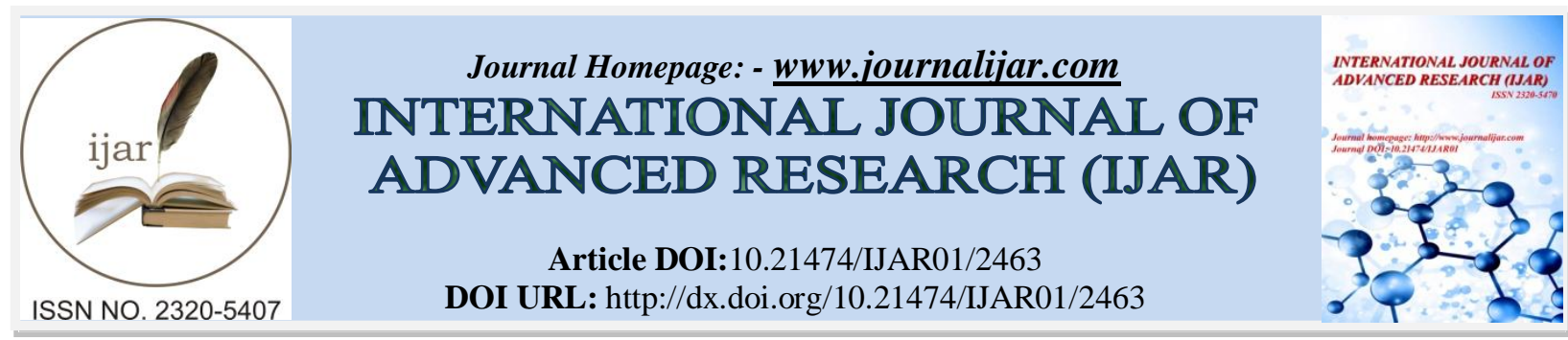

\title{
RESEARCHARTICLE
}

\section{CHARACTERISTICS OF THE CARCASS AND NUTRITIONAL VALUES OF BREED GRASSCUTTER MEAT (THRYONOMYS SWINDERIANUS) FED WITH PELLETS IN BENIN.}

\section{F. F. Aizoun ${ }^{1,2 *}$, S. C. B. Pomalegni ${ }^{1}$, C. D. S. J Gbemavo ${ }^{3}$, A. K. I. Youssao ${ }^{4}$, S. Farougou ${ }^{2}$, G. A. Mensah $^{1}$.}

1. Laboratory of Zootechnical, Veterinary and Halieutic Research (LRZV), Centre of Agricultural Research/Agonkanmey (CRA) of the National Institute of Agricultural Research of Benin (INRAB), 01 BP 884 Master recipe, Cotonou, 01 Republic of Benin.

2. Department of Animal Production and health, Biotechnology Research Unit of Production and Animal Health, Polytechnic School of Abomey-Calavi, University of Abomey-Calavi (UAC), 01 BP 2009 Cotonou, Benin.

3. Laboratory of Biomathematics and Forest Estimates (LABEF), Faculty of Agricultural Sciences, University of Abomey-Calavi (UAC), 04 BP 1525, Cotonou, Benin.

4. University of Abomey-Calavi (UAC),Polytechnic School of Abomey-Calavi (EPAC), Department of Animal Production and health, Laboratory of Research in Applied Biology, 01 BP 2009 Cotonou, Benin.

ManuscriptInfo

\section{Manuscript History}

Received: 23 October 2016

Final Accepted: 21 November 2016

Published: December 2016

Key words:-

Grasscutter breeding, pellets food, meat, carcass, nutrition.

\section{Abstract}

nutritional values of the meat of bred grasscutter fed with pellets.27 farmed grasscutters aged 7 months and of average weight $2.3 \mathrm{~kg}$ were used and divided into three groups of 9 grasscutters. The experimental device is a complete random block with three treatments and three replicates.At the end of the trial, one-third of the grasscutters were randomly selected from each group for determination of the carcass characteristics and nutritional value of the meat.Results showed that the live weight at slaughter of grasscutters varied from $2796 \pm 35.07 \mathrm{~g}$ to $2876 \pm 55.95 \mathrm{~g}$ ( $\mathrm{p}>0.05$ ). The difference was not significant between the cold carcass yield of grasscutters fed with the three pellets ( $>0.05)$. However, it was significant between the warm carcass yield of bred grasscutters $(\mathrm{p}<0.05)$. The length of the carcass varied from $26.46 \pm 0.57 \mathrm{~cm}$ to $27.82 \pm 0.58 \mathrm{~cm}$ in the grasscutters with the pellets ( $>0.05$ ). The meat of grasscutters contains a crude protein content ranging from $17.26 \pm 0.02$ to $22.6 \pm 0.02 \%$ and fat matter from $3.5 \pm$ 0.07 to $7.05 \pm 0.06 \%$. The difference between the moisture, protein and fat matter content between meats of the grasscutters fed with the three pellets was significant $(\mathrm{p}<0.05)$. The grasscutters bred fed with pellets 1 and 3 contain the best protein levels and low fat content.They can be used in grasscutters breeding for the production of grasscutters meats of good nutritional qualities.

Copy Right, IJAR, 2016,. All rights reserved.

The aim is to evaluate the

characteristics of the carcass and

\section{Introduction:-}

The breeding of non-conventional animal species is a mode of ex situ conservation of animal biodiversity which contributes to the coverage of animal protein requirements and to the improvement of incomes in tropical rural 
Africa in sub-Saharan Africa (Hanotte and Mensah 2002; Hardouin, 1986). Grasscutter breeding or the breed grasscutter (Thryonomys swinderianus) falls within this framework (IEMVT-CIRAD, 1992).Since its inception, grasscutter breeding is booming in Benin with more than 70,000 heads of grasscutters in captivity for more than 3,000 breeders (Mensahet al., 2013).It is a game very hunted in intertropical Africa for its meat appreciated by all and sold expensive compared to the beef, small ruminants and pork of current consumption (Baptist and Mensah, 1986).Vegetation fires and poaching are increasingly decreasing and favoring the replacement of game grasscutter by bred grasscutter (Mensah, 1991).Thus, grasscutter breeding can be suggested as an obvious solution for environmental problems (Karikari and Nyameasem, 2009).

In Benin, the breed grasscutters are mainly fed with a wide range of dry and fresh fodder with dietary supplements composed of energetic, nitrogen, vitamin and mineral matter (Mensah 1995; Tolebaet al., 2009). Some breeders supplement fodder with crop residues, agro-industrial products and kitchen remnants.However, faced with all-season feeding problems faced by growers, the production of complete pelleted feed can be the sustainable solution for feeding the grasscutters in captivity (Aïzounet al., 2015).Several studies on grasscutters in captivity have led to significant advances in feeding, reproductive control, zootechnical performance, ethology, age determination (Mensah, 2000, Sacramento et al., 2013 ), But few were devoted to the nutritional values of grasscutter meat, especially fed with pellets feed.The purpose of this study is to evaluate the characteristics of the carcass and to determine the nutritional values of grasscutter in captivity fed with pellets foods based on green fodder, maize products and by-products and other Food ingredients.

\section{Material and methods:-}

\section{Study sites:-}

The experiment was conducted in a grasscutter place of rearing of Non-Conventional Animal Species Breeding SubProgramm (S-PEEANC) of Zootechnical Veterinary and Halieutic Research Laboratory (LRZVH) in Agricultural Research Centre of Agonkanmey (CRA-Agonkanmey) in National Institute of Agricultural Research of Benin (INRAB) located in Commune of Abomey-Calavi. The climate is type Guinean, with two dry seasons and two rainy seasons. The average rainfall is $1.200 \mathrm{~mm}$ per year and average monthly temperatures vary between 27 and $31^{\circ} \mathrm{C}$ with relative humidity fluctuates between $65 \%$ from January to March and 97\% from June to July. The monthly average was between 27 and $31^{\circ} \mathrm{C}$ with a deviation of $3.2^{\circ} \mathrm{C}$ between the hottest month (March) and the least hot (August).

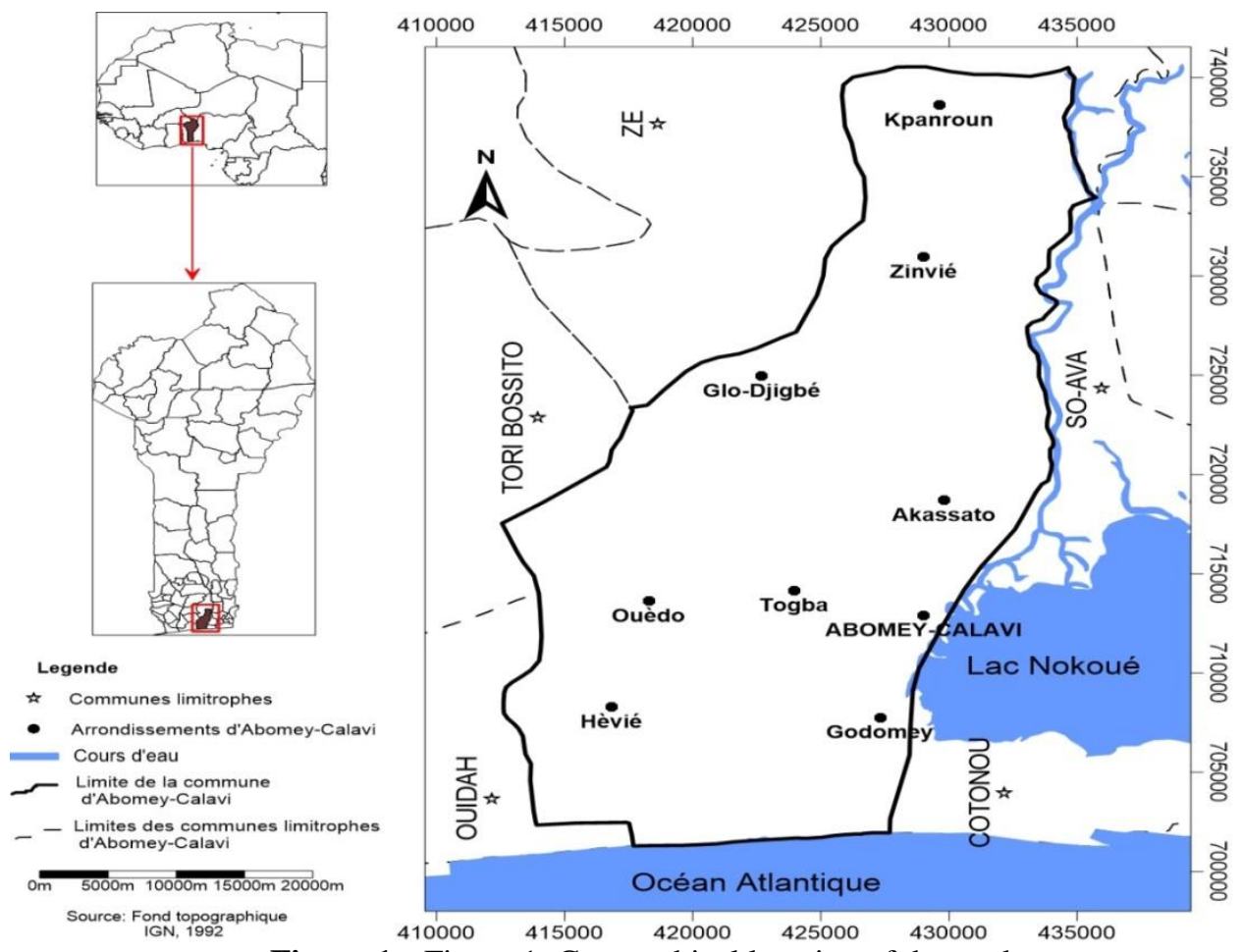

Figure 1:- Figure 1: Geographical location of the study area 


\section{Experimental device and data collection:-}

27 experimental grasscutters aged 7-month were used, divided into three groups with a live weight of $1928.4 \pm$ $51.99 \mathrm{~g} ; 2286 \pm 59.52 \mathrm{~g}$ and $2077.6 \pm 46.05 \mathrm{~g}$ respectively. The enclosures of rectangular shaped stage 3 levels were used for the conduct of grasscutter. The pens are divided into two compartments of size $(0.7 \mathrm{mx} 0.7 \mathrm{mx} 0.4 \mathrm{~m})$ communicated with a square opening of $0.2 \mathrm{~m}$ square drilled in a median wall and on the floor. This opening allowed the free passage of grasscutter from one compartment to another. For the experiment, the communication openings of the enclosure were closed by bricks to isolate animals. Each enclosure was equipped with feeder and waterer.

The 27 grasscutters were divided into three groups of nine (09) grasscutters and divided into three under-groups of three grasscutters. The device is a complete random block. Each block is made up of three subgroups or observation units.Each block received the three granulated foods with one granule per subgroup in the block.After subdividing them into a subgroup, the grasscutters underwent a food transition phase of ten (10) days following the recommendations made by Mensah and Ekué (2003).Food distribution occurred only once in the morning around 8 am. The water was served at ad libitum in the drinking troughs and renewed every day.

\section{Production of pellets:-}

After picking, the fodders were cut, dried in the shade. These fodder plants were crushed at the mill. Other food ingredients including maize grain, wheat bran, rice bran, cassava chips, cottonseed meal, soybean meal, the oyster shells and salt were also crushed. All forages and concentrates are placed in a blender to have a homogeneous mixture. The resulting mixture was then placed in an extruder to effect granulation. Three pellets were produced for testing. The pellet 1 consisted of green fodders and food supplements, the pellet 2 consisted of products and byproducts maize and the pellet 3 consisted of green fodders, food supplements and medicinal plants. The proportion and the quantity of ingredients used in the formulas are shown in Table 1.

Table 1:- Amount of ingredients for $100 \mathrm{~kg}$ of pellets

\begin{tabular}{|l|c|c|c|}
\hline \multirow{2}{*}{ Food Ingrédients } & \multicolumn{3}{|c|}{ Proportion of pellets (\%) } \\
\cline { 2 - 4 } & Pellets 1 & Pellets 2 & Pellets 3 \\
\hline Guinea Grass & 5,00 & - & 5,00 \\
\hline Ocimumgratissimum & - & - & 5,00 \\
\hline Ocimumbasilicum & - & - & 5,00 \\
\hline Vernoniaamygdalina & - & - & 5,00 \\
\hline Elephantgrass & 5,00 & - & - \\
\hline Paspalumvaginatum & 5,00 & - & - \\
\hline Leucaenaleucocephala & 3,00 & 4,00 & 3,00 \\
\hline Moringaoleifera & - & 4,00 & - \\
\hline Imperatacylindrica & - & - & - \\
\hline Papayaseeds & & & 16,00 \\
\hline Maize grain & 30,00 & 28,50 & 20,00 \\
\hline Maize bran & 18,00 & 30,00 & 15,00 \\
\hline Maizeflour & - & 14,00 & - \\
\hline Rice bran & 8,00 & 10,00 & 8,00 \\
\hline wheat bran & 8,00 & - & 8,00 \\
\hline Cotton cake & 8,00 & - & 8,00 \\
\hline Soyabeanmeal & 8,00 & - & - \\
\hline Maize spathe & - & 7,50 & - \\
\hline Cassavaroot & - & - & - \\
\hline Oyster shellpowder & 1,50 & 1,50 & 1,50 \\
\hline Salt & 0,50 & 0,50 & 0,50 \\
\hline Total & 100 & 100 & 100 \\
\hline
\end{tabular}

\section{Laboratoryanalysis of the pellets:-}

Food samples offered and rejected of different pellets were collected and analyzed using the methods allowed by the Interprofessional Office of Analytical Studies (BIPEA, 1976) and Association of Official Analytical Chemist (AOAC, 2000). These analyzes were performed at Laboratories of Sciences of sol Water and Environment (LSSEE) in National Institute of Agricultural Research of Benin (INRAB) and Laboratory of Sciences and Animal Production 
Techniques of the Faculty of Agricultural Sciences (FSA) of University of Abomey-Calavi (UAC). The Determination of dry matter (DM) was made by drying by placing in an oven at $105^{\circ} \mathrm{C}$ for $24 \mathrm{~h}$ to stabilize the weight and then weighed after it has cooled. This is for remove any residual water. The determination of the crude protein content was made by the method Kjeldahl (AOAC, 2000), the crude fiber by the method of Van Soestet al. (1991), the fat was determined by the Soxhlet device (AOAC, 2000) and that of crude ash by carbonization slow at oven. The contents of calcium and phosphorus are assayed by atomic absorption spectrophotometry.

\section{Characteristics of the carcass of farmed grasscutters:-}

Three grasscutters of each group randomly selected and sacrificed at the end of the experiment to analyze the characteristics of the carcass.Before slaughter, the grasscutters were dieters for 24 hours but had access to water.After sacrificing the animals, they were depilated with boiling water, eviscerated, weighed and refrigerated at $4^{\circ} \mathrm{C}$ for 24 hours to obtain the weight of the cold carcass. The parameters studied are the live weight at slaughter, the weight of the warm carcass, the weight of the cold carcass, the weight of the heart, the weight of the liver, lungs, kidneys, carcass length, yield in hot carcass and cold carcass. The formulas used to calculate the carcass yield variables are as follows:

Warm carcass yield $=($ Warm carcass weight $/$ live weight $) \times 100$

Cold Carcass Yield $=($ Cold Carcass Weight $/$ Live Weight $) \times 100$

\section{Nutritional qualities of meat of bred grasscutters:-}

The determination of the chemical composition of the meat concerned the main nutrients and certain minerals.For this purpose, each analysis is based on 3 trials of $10 \mathrm{~g}$ of fresh grasscutter. The chemical elements determined were:Dry matter (DM), moisture (\%), Crude protein, Fat and Total ash. The contents were determined according to the methods of the Association of Official Analytical Chemist (AOAC, 2000). The dry matter (DM) and moisture were determined by drying by placing in an oven at $105{ }^{\circ} \mathrm{C}$ for 24 hours until the weight was stabilized and then weighed after allowing it to cool.The determination of the crude protein content was made by the method of Kjeldahl (AOAC, 2000), that of the lipids was determined by the Soxhlet device (AOAC, 2000) and that of the total ash by slow charring in the oven at $550^{\circ} \mathrm{C}$. His analyzes were carried out at the Laboratory of the School of Nutrition of Sciences and Food Technologies of the Faculty of Agronomic Sciences (FSA) of UAC.

\section{Statistical analysis of data:-}

The descriptive statistic was performed in terms of mean and standard deviation for the data.The Royan-Joiner normality test and the variance equality test were performed to test respectively the normality and the equality of the variances.In the case of normality, an analysis of variance (ANOVA) was performed for the nutrient values of the pellets, carcass characteristics, organ weights and nutritional values of the meat.Otherwise, the nonparametric Kuskal-Wallis test was performed at the 5\% threshold.In case of significant differences between the averages for a parameter following the three pellets, the Student Newman \&Keuls averaging test was performed at the 5\% threshold.The analyzes were carried out with software R3.0.2 (R Development Core Team, 2012. http://www.Rproject.org/).

\section{Results:-}

Nutrient values of pellets:-

The bromatological analysis of the three pellets gives the nutrient values shown in Table 2.The dry matter and fat content of the three pellets was not significantly different ( $>0.05)$. On the other hand, the content organic matter and total carbon content was significantly different for the three pellets $(\mathrm{p}<0.05)$, as well as that for crude protein, crude fiber, total ash, calcium and phosphorus for the three pellets $\mathrm{P}<0.05)$.

Table 2:-Chemical composition of the pellets

\begin{tabular}{|l|l|l|l|l|}
\hline \multirow{2}{*}{ Parameters } & \multicolumn{2}{c|}{ Chemical composition of the pellets } & \multirow{2}{*}{ Prob } \\
\cline { 2 - 4 } & \multicolumn{1}{|c|}{ Pellet 1 } & \multicolumn{1}{c|}{ Pellet 2 } & Pellet 3 & \multirow{2}{*}{} \\
\cline { 2 - 4 } & Mean \pm ET & Mean \pm ET & Mean \pm ET & \\
\hline Dry matter (\%) & $90.04 \pm 0.09$ & $90.33 \pm 0.03$ & $90.33 \pm 0.03$ & 0.1637 \\
\hline Organicmatter(\% MS) & $93.34 \pm 0.02 \mathrm{~b}$ & $94.05 \pm 0.03 \mathrm{a}$ & $92.75 \pm 0.01 \mathrm{c}$ & $5.88 \mathrm{e}-07$ \\
\hline Crudeprotein(\% MS) & $17.59 \pm 0.02 \mathrm{a}$ & $10.73 \pm 0.01 \mathrm{c}$ & $14.09 \pm 0.02 \mathrm{~b}$ & 0.01556 \\
\hline Crude fibre (\% MS) & $9.02 \pm 0.12 \mathrm{a}$ & $7.23 \pm 0.16 \mathrm{c}$ & $8.21 \pm 0.14 \mathrm{~b}$ & 0.01556 \\
\hline Fat (\% MS) & $2.16 \pm 0.10$ & $2.09 \pm 0.03$ & $2.27 \pm 0.04$ & 0.26987 \\
\hline Totalashes(\% MS) & $6.66 \pm 00 \mathrm{~b}$ & $5,95 \pm 0.01 \mathrm{c}$ & $7.25 \pm 0.01 \mathrm{a}$ & 0.01455 \\
\hline
\end{tabular}




\begin{tabular}{|l|l|l|l|l|}
\hline total carbon $(\% \mathrm{MS})$ & $46.67 \pm 00 \mathrm{~b}$ & $47.02 \pm 0.01 \mathrm{a}$ & $46.38 \pm 0.01 \mathrm{c}$ & $2.76 \mathrm{e}-11$ \\
\hline $\mathrm{Ca}(\% \mathrm{MS})$ & $0.64 \pm 0.02 \mathrm{c}$ & $0.88 \pm 00 \mathrm{~b}$ & $0.95 \pm 0.02 \mathrm{a}$ & 0.01455 \\
\hline $\mathrm{P}(\% \mathrm{MS})$ & $0.42 \pm 0.01 \mathrm{a}$ & $0.33 \pm 0.03 \mathrm{~b}$ & $0.47 \pm 0.02 \mathrm{a}$ & 0.00738 \\
\hline
\end{tabular}

ET = Error-Type. Values followed by different letters $(\mathrm{a}, \mathrm{b}, \mathrm{c})$ on the same line are significantly different according to Student Newman \&Keuls test at the threshold $5 \%$. Prob = Probability.

\section{Characteristics of the carcass of bred grasscutters fed with the pellets:-}

Table 3 summarizes the characteristics of the carcass in the grasscutters fed with the different pellets. The results showed that the slaughter weight of the grasscutters fed with pellets varied from $2796 \pm 35.07 \mathrm{~g}$ to $2876 \pm 55.95$ g.The difference between the slaughter weight of the grasscutters fed with the different pellets was not significant ( $>$ >0.05). The warm carcass weights obtained from the grasscutters fed with pellets were $2876 \pm 55.95 \mathrm{~g}, 2796 \pm$ $35.07 \mathrm{~g}$ and $2844 \pm 64.26 \mathrm{~g}$, respectively. The difference was not significant between the weight of the warm carcass of grasscutters fed with pellets 2 and 3 as well as the grasscutters fed with pellets 1 and 3 (p>0.05). On the other hand, this difference between the weight of the warm carcass of the grasscutters fed with the pellets 1 and 2 is significant $(\mathrm{p}<0.05)$. The same holds for the weight of the cold carcass $(\mathrm{p}<0.05)$. The cold carcass yield of the grasscutters ranged from $61.13 \pm 1.44 \%$ to $63.99 \pm 1.93 \%$ without significant difference $(p>0.05)$. The hot carcass yield of grasscutters fed with pellets ranged from $64.22 \pm 2.09 \%$ to $70.75 \pm 2.22 \%$. The difference between the warm carcass yields of the grasscutters fed with pellets 1 and 3 was not significant $(p>0.05)$. On the other hand, this difference was significant between the warm carcass yield of the grasscutters fed with pellets 1 and 3 compared to grasscutters fed with pellets $2(\mathrm{p}<0.05)$.Carcass length $27.82 \pm 0.58 \mathrm{~cm}$ was obtained in grasscutters fed with pellets $1 ; 27.3 \pm 0.47 \mathrm{~cm}$ and $26.46 \pm 0.57 \mathrm{~cm}$ were obtained in grasscutters fed with pellets 3 and pellets 2 respectively. No significant difference was found between carcass lengths of grasscutters fed with the three pellets $(\mathrm{p}>0.05)$.

Table 3:-Characteristics of the carcass of grasscutters fed with the pellets.

\begin{tabular}{|c|c|c|c|c|}
\hline \multirow[b]{2}{*}{ Parameters } & Pellet 1 & Pellet 2 & Pellet 3 & \multirow[b]{2}{*}{ Prob } \\
\hline & Mean \pm ET $(n=3)$ & Mean \pm ET $(n=3)$ & Mean \pm ET $(n=3)$ & \\
\hline Live weight at slaughter $(\mathrm{g})$ & $2876 \pm 55.95 \mathrm{a}$ & $2796 \pm 35.07 \mathrm{a}$ & $2844 \pm 64.26 \mathrm{a}$ & 0.487916 \\
\hline Weight of the warm carcass $(\mathrm{g})$ & $2035.8 \pm 102.51 \mathrm{a}$ & $1796 \pm 75.12 b$ & $1960.6 \pm 65.78 \mathrm{ab}$ & 0.027325 \\
\hline Weight of the cold carcass $(\mathrm{g})$ & $1840 \pm 44.30 \mathrm{a}$ & $1709.6 \pm 59.25 b$ & $1770.6 \pm 34.45 \mathrm{ab}$ & 0.039843 \\
\hline Hot carcassyield(\%) & $70.75 \pm 2.22 \mathrm{a}$ & $64.22 \pm 2.09 \mathrm{~b}$ & $68.92 \pm 0.91 \mathrm{a}$ & 0.002531 \\
\hline Cold carcassyield(\%) & $63.99 \pm 1.93 \mathrm{a}$ & $61.13 \pm 1.44 \mathrm{a}$ & $62.45 \pm 0.89 a$ & 0.128251 \\
\hline Length of the carcass $(\mathrm{cm})$ & $27.82 \pm 0.58 \mathrm{a}$ & $26.46 \pm 0.57 \mathrm{a}$ & $27.3 \pm 0.47 \mathrm{a}$ & 0.359178 \\
\hline
\end{tabular}

$\mathrm{ET}=$ Error-Type. Values followed by different letters $(\mathrm{a}, \mathrm{b}, \mathrm{c})$ on the same line are significantly different according to Student Newman \&Keuls test at the threshold $5 \%$. Prob = Probability.

Effects of pellets on the weight of organs of grasscutters:-

Table 4 shows the weight of certain organs of grasscutters fed with the pellets produced.The heart weight of grasscutters fed with pellet 1 was highest $(20.4 \pm 1.82 \mathrm{~g})$ and that of grasscutters fed with pellet 2 was the lowest $(13.2 \pm 1.30 \mathrm{~g})$.The highest liver weight $18.6 \pm 1.95 \mathrm{~g}$ was obtained in grasscutters fed with pellet 3 and the lowest $12.8 \pm 1.92 \mathrm{~g}$ was recorded in grasscutters fed with pellet 1 . The kidney weight recorded in grasscutters fed with the three pellets varied from $9.2 \pm 1.30 \mathrm{~g}$ to $10.4 \pm 1.14 \mathrm{~g}$. The lowest lung weight $12.4 \pm 1.14 \mathrm{~g}$ was obtained in grasscutters fed with pellet 2 and the high $14.2 \pm 0.84 \mathrm{~g}$ was recorded in grasscutters fed with pellet 1 . The difference was significant between the heart weight of the grasscutters fed with the three pellets $(p<0.05)$. The same applies to the weight of the liver and the weight of the lung.On the other hand, the difference was not significant between the kidney weight of the grasscutters fed with the three pellets ( $p>0.05)$.

Table 4:-Weight of organs of grasscutters fed with pellets

\begin{tabular}{|l|l|l|l|c|}
\hline Parameters & Pellet 1 & Pellet 2 & Pellet 3 & \multirow{2}{*}{ Prob } \\
\cline { 2 - 5 } & Mean \pm ET $(\mathrm{n}=3)$ & Mean \pm ET $(\mathrm{n}=3)$ & Mean \pm ET $(\mathrm{n}=3)$ & 0.037983 \\
\hline HeartWeight $(\mathrm{g})$ & $20.4 \pm 1.82 \mathrm{a}$ & $13.2 \pm 1.30 \mathrm{c}$ & $15 \pm 2.24 \mathrm{~b}$ & 0.012167 \\
\hline Liverweight(g) & $12.8 \pm 1.92 \mathrm{~b}$ & $14.8 \pm 2.39 \mathrm{~b}$ & $18.6 \pm 1.95 \mathrm{a}$ & 0.236879 \\
\hline Weight of the kidney $(\mathrm{g})$ & $10.4 \pm 1.14$ & $9.2 \pm 1.30$ & $9.8 \pm 1.48$ & 0.012358 \\
\hline Lung Weight(g) & $14.2 \pm 0.84 \mathrm{a}$ & $12.4 \pm 1.14 \mathrm{c}$ & $13.2 \pm 1.30 \mathrm{~b}$ & \\
\hline
\end{tabular}

ET = Error-Type. Values followed by different letters $(\mathrm{a}, \mathrm{b}, \mathrm{c})$ on the same line are significantly different according to Student Newman \&Keuls test at the threshold $5 \%$. Prob = Probability. 
Nutritional values of meat of grasscutters fed with pellets:-

Table 5 shows the nutrient values of the meat of grasscutters fed with pellets. The analysis of the results shows that the dry matter and total ash in the meat of the grasscutters was not significantly different between the three pellets $(p>0.05)$. The difference between the moisture, protein and fat content in the meat of the grasscutters fed with the three pellets was significant $(\mathrm{p}<0.05)$.

Table 5:-Nutrient values of grasscutter meat

\begin{tabular}{|l|l|l|l|l|}
\hline \multirow{2}{*}{ Variables } & \multicolumn{1}{|c|}{ Pellet 1 } & \multicolumn{1}{c|}{ Pellet 2 } & \multicolumn{1}{c|}{ Pellet 3 } & \multirow{2}{*}{ Prob } \\
\cline { 2 - 4 } Dry matter $(\%)$ & Mean \pm ET $(\mathrm{n}=3)$ & Mean \pm ET $(\mathrm{n}=3)$ & Mean \pm ET $(\mathrm{n}=3)$ & 0.678512 \\
\hline Moisture(\%) & $22.87 \pm 0.10 \mathrm{a}$ & $20.78 \pm 0.15 \mathrm{a}$ & $21.86 \pm 0.03 \mathrm{a}$ & 0.051257 \\
\hline Crudeprotein(\%) & $77.13 \pm 0.10 \mathrm{c}$ & $79.22 \pm 0.15 \mathrm{a}$ & $78.14 \pm 0.03 \mathrm{~b}$ & 0.023579 \\
\hline Fat $(\%)$ & $19.5 \pm 0.06 \mathrm{~b}$ & $17.26 \pm 0.02 \mathrm{c}$ & $22.6 \pm 0.02 \mathrm{a}$ & 0.045842 \\
\hline Total ashes(\%) & $6.36 \pm 0.18 \mathrm{~b}$ & $7.05 \pm 0.06 \mathrm{a}$ & $3.5 \pm 0.07 \mathrm{c}$ & 0.235416 \\
\hline
\end{tabular}

ET = Error-Type. Values followed by different letters (a, b, c) on the same line are significantly different according to Student Newman \&Keuls test at the threshold $5 \%$. Prob = Probability.

\section{Discussion:-}

Nutrient values of pellets:-

The chemical composition of the pellets produced and used in this study can be compared with those found in the literature.The dry matter values of the pellets obtained (90.04 to 90.33\%) are similar to those obtained (90.92$91.25 \%$ ) by Wogar (2012). They are greater than the values varying between: 83.3 to $88.5 \%$ obtained by Fantodjiet al. (2003); 76,37-89,15 found by Traoréet al. (2009); 86.65 reported by Wogar and Yara (2015); 80.7-89.49\% obtained by Soroet al. (2014) ; 85-88.50 recorded by Seiduet al. (2016).But these values are lower than those varying between 94-97\% obtained by Okeke and Mogbo (2013). The organic matter contents varying between 92.75 and $94.05 \%$ are similar to those reported by Traoréet al. (2008), Traoreet al. (2009) and Ngoulaet al. (2012). The crude protein levels obtained in this study for pellets 1 and $3(14.09$ and $17.59 \%)$ are in the range of $12-18.5 \%$ and 14-18\% dry matter recommended for grasscutters (Mensah, 1993, Mensah, 1995, Adeniji, 2009). The crude protein contents of pellets 1 and 3 obtained in this study belong to the intervals: 11.5-20.2\% reported by Traoréet al. (2009); 11.62-20.20\% recorded by Wogaret al. (2013).All protein values found for the three pellets are in the 9.6-24.5\% range obtained by Fantodjiet al. (2003); 10.45-21.90 found by Wogar and Ayuk (2012).However, these values are lower than the intervals 20.88-22.98 found by Okeke and Mogbo (2013) and 17.90-20.6\% reported by Seiduet al. (2016).

The fiber contents ( 7.23 to $9.02 \% \mathrm{DM}$ ) obtained during our work are in the range $6.70-18.56 \%$ obtained by Ngoulaet al. (2012); 4.35-21.45\% reported by Wogar (2015). These values are greater than 6.01-6.26\% and 3.99$4.52 \%$ obtained respectively by wogar (2012) and Okerekeet al. (2015).They are also lower than 13.23-17.90\% found by wogar (2011); 11-21 (Okeke and Mogbo, 2013) and 16.67-19.79\% (Seiduet al., 2016).The values (5.95$7.25 \% \mathrm{DM}$ ) of total ash found in this study belong to the 6-9\% range reported by Seiduet al. (2016). They are similar to 3.29-7.09\% found by Ngoulaet al. (2012). These values are less than 8.68-10.33\% obtained by Traoréet al. (2009); 11.75-11.87\% found by Wogar and Ayuk (2012) and 25-35\% reported by Okeke and Mogbo (2013).Calcium levels (0.64-0.95\%) obtained in this study are similar to 0.35-0.9\% found by Schrage and Yewadan (1999); 0.2-0.7\% obtained by Pond et al. (1995); 0.32-0.66\% reported by Traoréet al. (2009); 0.71 recorded by Soroet al. (2014) ; $0.82-0.85 \%$ found by Seiduet al. (2016). They belong to the range $0.058-1 \%$ reported by Ngoulaet al. (2012). The phosphorus levels $(0.33-0.47 \%)$ found during this work are in agreement with the values $0.26-0.42 \%$ obtained by Traoréet al. (2009) and 0.3-0.33\% recorded by Seiduet al. (2016).They are less than 0.53\% found by Soroet al. (2014).The fat contents (2.09-2.27\% DM) obtained for the pellets are respectively between $2.5-4.5 \%$ recommended (Mensah, 1993; Mensah, 1995).They are also in agreement with those reported by Soroet al. (2014) and Traoreet al. (2009).But these values are less than 8.02-8.82\% (Okeke and Mogbo, 2013).Differences in the different nutrients between this study and the various works cited may be due to the quality and quantity of the different food ingredients used in the composition of the food. 


\section{Effects of pellets on the characteristics of the carcass of grasscutters:-} Slaughter weight and carcass of grasscutters:-

The slaughter weight of the grasscutters fed with the types of pellets is $2876 \pm 55.95 \mathrm{~g}, 2796 \pm 35.07 \mathrm{~g}$ and $2844 \pm$ $64.26 \mathrm{~g}$ respectively for pellet 1 ; pellet 2 and pellet 3.These weights at slaughter are superior to slaughter weights $2450 \mathrm{~g}, 2223 \mathrm{~g}, 1887 \mathrm{~g}$ obtained in grasscutters fed on concentrated feeds containing different levels of Panicummaximun (Karikari and Nyameasem, 2009); 1201.84g; $1208.39 \mathrm{~g}$ and $1226.53 \mathrm{~g}$ reported by Pokuet al. (2013).But they belong to the interval $2494 \mathrm{~g}-3630 \mathrm{~g}$ reported by Zyl van et al. (1999b).They are lower than slaughter weights $4990 \mathrm{~g} ; 5960 \mathrm{~g}$ and $5400 \mathrm{~g}$ obtained by Okoruwaet al.(2014).

The weights of the warm carcass obtained in the grasscutters fed with the three types of pellets $(2035.8 \pm 102.51 \mathrm{~g}$, $1796 \pm 75.12 \mathrm{~g}$ and $1960.6 \pm 65.78 \mathrm{~g}$ ) are greater than the values $1513 \mathrm{~g}, 1319 \mathrm{~g}$ and $1064 \mathrm{~g}$ found by Karakari and Nyameasem (2009); 1370.03g 1456.23g and 1264.02g reported by Henry et al. (2012) and $1615 \mathrm{~g}, 1408 \mathrm{~g}$ and 2116 $\mathrm{g}$ obtained by Zyl van et al. (1999a).But these values that we obtained are less than 3025,29g; 4089.12g and 3505g found by Okoruwaet al. (2014). The weights of the cold carcass obtained in the grasscutters fed with the three types of pellets $(1840 \pm 44.30 \mathrm{~g}, 1709.6 \pm 59.25 \mathrm{~g}$ and $1770.6 \pm 34.45 \mathrm{~g})$ are greater than the values $1477 \mathrm{~g}, 1287 \mathrm{~g}$ and $1037 \mathrm{~g}$ reported by Karakari and Nyameasem (2009).But they are less than $2030 \pm 0.11 \mathrm{~g}$ found by Omoleet al. (2005).

\section{Carcass yield of grasscutters:-}

The hot carcass yields obtained in this study $(70.75 \pm 2.22 \%, 64.22 \pm 2.09 \%$ and $68.92 \pm 0.91 \%)$ are higher than those reported byKarakari and Nyameasem (2009) between $56.4 \%$ and $61.8 \%$.Similarly, cold carcass yields (63.99 \pm $1.93 \%, 61.13 \pm 1.44 \%$ and $62.45 \pm 0.89 \%$ ) were found to be higher than those obtained by the same authors varying between $55 \%$ and $60.3 \%$. The hot carcass and cold carcass yields obtained in this study are greater than $54 \%$ found by Joriet al. (1995) and those between $56.8 \%$ and $57.9 \%$; 50.41-55.26\%; $50.12 \pm 065 \%$ at $57.79 \pm 0.51 \%$ reported respectively by Zyl van et al. (1999b), Annoret al. (2008) and Traoreet al. (2009).The hot carcass yields found $(64.22 \pm 2.09 \%$ at $70.75 \pm 2.22 \%)$ in this study belong to $65.12 \%$ to $75.42 \%$ for the carcass yield reported by Seiduet al. (2016) in Ghana and 65\% -80\% found by Fayenuwoet al. (2003).

The cold carcass yields found $(63.99 \pm 1.93 \%, 61.13 \pm 1.44 \%$ and $62.45 \pm 0.89 \%)$ are similar to the carcass yields $64 \%$ for male and female and $63.8 \pm 2.43 \%$ reported by Joriet al. (1995) and Ajayi and Tewe (1980) and belong to the $60.63 \%$ to $68.61 \%$ range obtained by Okoruwaet al. (2014). The carcass yields obtained in this study were less than $76.98 \pm 3.28 \%$ found by Omole et al. (2005) and at intervals 71.80 to $82.30 \%$ for the grasscutters reported by Henry and Njume, 2008); $88.83 \%$ to $89.07 \%$ found by Henry et al. (2012) and $70.2 \%$ to $72.1 \%$ obtained by Pokuet al. (2013). The lengths of the carcass $(27.82 \pm 0.58 \mathrm{~cm}, 26.46 \pm 0.57 \mathrm{~cm}$ and $27.3 \pm 0.47 \mathrm{~cm})$ obtained in this study are similar to $25.6 \mathrm{~cm} ; 27.3 \mathrm{~cm}$ and $27.8 \mathrm{~cm}$ reported by Nyameasem (2010).

\section{Impact of pellets on the weight of Lung, Liver, Kidney and Lung Organs of Grasscutters:-}

The heart weights of the grasscutters fed with the three pellets in this study are comparable to those found in the literature.Its heart weights are similar to the $15.45 \mathrm{~g}, 19.10 \mathrm{~g}$ and $21.45 \mathrm{~g}$ found by Seiduet al. (2016). They are greater than $11.0 \mathrm{~g} ; 12.0 \mathrm{~g}$ and $12.8 \mathrm{~g}$ found for the heart weight by Nyameasem (2010) and $10.45 \mathrm{~g}, 9.18 \mathrm{~g}$ and 8.14 $\mathrm{g}$ reported by Henry et al. (2012).However, they are less than $23 \pm 0.005 \mathrm{~g}$ obtained by Omoleet al.(2005).

The liver weights of the grasscutters fed with the three pellets are less than $77 \pm 0.023 \mathrm{~g}$ reported by Omole et al. (2005); $53.8 \mathrm{~g} ; 48.0 \mathrm{~g}$ and $47 \mathrm{~g}$ found by Nyameasem (2010); $21.95 \mathrm{~g}, 23.98 \mathrm{~g}$ and $20.07 \mathrm{~g}$ obtained by Henry et al. (2012) and $26.53 \mathrm{~g}, 45.45 \mathrm{~g}$ and $46.52 \mathrm{~g}$ found by Seiduet al. (2016). The kidney weights of the grasscutters fed with the three pellets obtained in this study are similar to the values $9.67 \mathrm{~g}$ and $10 \mathrm{~g}$ found by Nyameasem (2010); Varying between $8.23 \mathrm{~g}$ and $14.23 \mathrm{~g}$ reported by Seiduet al.(2016).They are greater than $6.58 \mathrm{~g}, 6.28 \mathrm{~g}$ and $7.02 \mathrm{~g}$ found by Henry et al. (2012) but less than $20 \pm 0.001 \mathrm{~g}$ obtained by Omoleet al. (2005).The lung weight obtained in the grasscutters fed with pellets in this study is similar to $12.30 \mathrm{~g} ; 17.53 \mathrm{~g} 18.35 \mathrm{~g}$ reported by Seiduet al. (2016).

\section{Nutritional values of meat of grasscutters fed with pellets:-}

The level of dry matter contained in the meat of the grasscutters fed with the three pellets varied between $20.78 \pm$ 0.15 and $22.87 \pm 0.10 \%$ with no significant difference ( $p>0.05$ ). The moisture content in meats grasscutter $77.13 \pm$ $0.10 \% ; 78,14 \pm 0,03 \%$ and $79,22 \pm 0,15 \%$ in this study is superior to those reported by Pokuet al. (2013) and Seiduet al. (2016).But they are similar to those obtained by Ella et al. (2014) in Côte d'Ivoire in wild grasscutters $75 \%$ in females and $76 \%$ in males. The crude protein levels obtained in this study are similar to those ranging from 18.78 to 
21.12\% obtained by Wogaret al. (2013); 16.32 and 22.03\% reported by Seiduet al. (2016). The level of protein obtained in the meat of grasscutters fed with pellet 2 is similar to $18.1 \pm 0.5 \%$ in males and females reported by Zyl van et al. (1999b).But this rate is less than $22.7 \%$ recorded by Asibey (1974), with values varying between $20.91 \%$ and $22.56 \%$ found by Pokuet al. (2013); to $20.04 \pm 0.4 \%$ obtained by Ella et al. (2014) in wild grasscutter.The fat levels obtained in this study are lower than values between $9.2 \pm 1.9 \%$ and 10.1 in females; to $6.5 \pm 2 \%$ in males and $8.3 \pm 2.3 \%$ in both sexes reported by Zyl van et al. (1999b). They are also lower than the rates included between $11.92 \%$ and $12.64 \%$ found by Wogaret al. (2013).But the values obtained in this study are higher than those included between $0.90 \%$ and $2.09 \%$ recorded by Pokuet al. (2013); to $4 \pm 0.13 \%$ in the female and $1.5 \pm 0.16 \%$ in the male to the wild grasscutter obtained by Ella et al. (2014) and values varying between $1.6 \%$ and $3.12 \%$ reported by Seiduet al. (2016). The total ash obtained in meat of grasscutters fed with pellets is higher than the $0.92 \%$, $1.14 \%$ and $0.85 \%$ ash levels reported by Pokuet al. (2013) and $0.5 \%, 0.61 \%$ and $0.63 \%$ obtained by Seiduet al. (2016). They are also greater than $1 \pm 0.1 \%$ in the female and $1 \pm 0 \%$ in the male for wild grasscutters reported by Ella et al. (2014).

\section{Conclusion:-}

All the results obtained during this study show that the pellets produced have a positive influence on the carcass yield, the weight of the organs and the nutritional quality of the meat of the grasscutters which consume them. The meat of grasscutters fed with the various pellets has appreciable nutritional characteristics. Meat of animals fed with the pellets based from green fodder, maize products and by-products, and medicinal plants has a lower fat content and higher protein content compared to meat of grasscutters fed with the pellets based from green fodder pellets, products and by-products of maize, and other food ingredients. The production and use of these pellets in grasscutter breeding will make it possible to raise grasscutters with a meat of good nutritional qualities.

\section{Acknowledgements:-}

We thank the authorities of the National Institute of Agricultural Research of Benin (INRAB) for allowing the work we were doing in the center. We also thank the Frame work Programme to Support Agricultural Diversification (ProCAD) through the Agricultural Productivity Programme in West Africa (WAAPP) for financial support.

\section{References:-}

1. Adéniji, A.A. (2009): Protein and Energy Requirements of Weaner Grasscutters. Animal Nutrition and Feed Tech., 9: 73-79.

2. Aïzoun F.F., Pomalegni, S.C.B., Farougou, S., and Mensah, G.A. (2015): Literature review on feeding of grasscutter with of pellets of green fodders in Benin. ASA, 19(2): 389-400. 2015 ISSN 1669-5009. 12p.

3. Ajayi, S.S.andTewe, O.O. (1980): Food Preferences and Carcass Composition of the Grasscutter (Thryonomys swinderianus) in Captivity. Afr. J Ecol; 18: 133-140.

4. Asibey, O.A.E.(1974):The grass-cutter, Thryonomys swienderianusTemmlnck in Ghana. Symp.Zool. Soc. Lond. 34, 161-170.

5. Annor A.Y., Kagya-Agyeang J.K., Abbam, J.E.Y., Oppong, S.K., Agoe, I.M. (2008): Growth performance of grasscutter (Thryonomys swinderianus) eating leaf and stem fractions of Guinea grass (Panicummaxmium). Livest. Res. Rural Dev., 20: 125.

6. AOAC, (2000): Official Methods of Analysis of AOAC International 16th edn., P. Cunniff. AOAC International, Arlington, Virginia, USA: Association of Official Analytical Chemist, p 945-1431.

7. Baptist, R. etMensah G.A. (1986):The cane rat. Farm animal of the future. World Animal Review60 : 2-6.

8. BIPEA, (1976): Bureau Interprofessionnel d'Etudes analytiques. Recueil des méthodes d'analyses des communautés Européennes : 2 route du port Charbonnier, 92230 Gennevilliers, 140p.

9. Ella NTEME, G.S., Aoussi, S.,Kouamé, P., Fantodji, A. et Bakou, S. (2014) : Détermination de la couleur et de la valeur nutritionnelle de la viande d'aulacodes sauvages (Thryonomys swinderianus, Temminck, 1827).Int. J. Biol. Chem.Sci. 8(2):610-620.

10. Fantodji, A., B. Traoré, etKouamé, L.P. (2003): Impact of Brewery refuse and Leucaenaleucocephala as food supplement on cane rat growth under breeding conditions. AgronomieAfricaine, 15(1): 39-50.

11. Fayenuwo, J. O., Akande, M., Taiwo, A. A., Adebayo, A. O., Saka, J. O., Lawal, B., Oyekan, P. O. (2003):"Guidelines for Grasscutter Rearing Technical Bulletin-Institute of Agricultural Research and Training. ObafemiAwolowoUniversity, Ibadan, Nigeria.

12. Hardouin, J. (1986) : Mini-élevage et sources méconnues de protéines animales. Annales de Gembloux, 92: 153-162. 
13. Hanotte, O., Mensah, G.A. (2002): Biodiversity and domestication of 'non-conventional' species: a worldwide perspective. $7^{\text {th }}$ World. Congress on Genetics Applied to Livestock Production, 19-23 August 2002, Montpellier, France, vol.30.Sur CD Rom et site web http//www.wogalp.org -pp.543-546.

14. Henry, A.J. and Njume, G.N. (2008): Effect of varied energy levels on the carcass characteristics of grasscutters (Thryonomys swinderianus). Proceeding 33rd Annual Conference of Nigerian Society for Animal Production (pp. 168-170), Ogun State.

15. Henry, A.J., Ibe S.N., and Asuquo, B.O. (2012): Effect of weaning age on growth and slaughter characteristics of grasscutters (Thryonomys swinderianus) raised under intensive management in the humid tropics. J. Agr. Sci., 4(12): 232-246.

16. IEMVT-CIRAD.(1992) : L'élevage de l'aulacode. Fiche techniques d'élevage tropical. Productions Animales. Ministère de la Coopération et du Développement. Maisons Alfort. $\mathrm{N}^{\circ} 2,10 \mathrm{p}$.

17. Jori, F., Mensah, G.A., \&Adjanohoun, E. (1995):Grasscutter (Thryonomys swinderianus) production: An example of rational exploitation of Wildlife. Biodiversity \& Conservation, 4(2), 257-265.

18. Karikari, P.K. and Nyameasem, J.K.(2009): Productive Performance and Carcass Characteristics of Captive Grasscutters (Thryonomys swinderianus) Fed Concentrate Diets Containing Varying Levels of Guinea Grass. World Applied Sciences Journal 6(4): 557-563.

19. Mensah, G.A. (1991) : Elevage des espèces de gibier : cas de l'aulacodiculture. (Elevage de l'aulacode: Thryonomys swinderianus). Mémoire special. Chapitre D: Gestion du patrimoine forestier. Gestion de la faune sylvestre. $10^{\text {ème }}$ Congrès Forestier Mondial 'La forêt, Patrimoine de l'Avenir ', Paris 17 au 26 septembre 1991. Revue ForestièreFrançaise, Hors série, Vol. N 5, pp, 301-309.

20. Mensah, G.A., Pomalegni, S.C.B., AhoyoAdjovi, N.R., Mensah, E.R., Guedou, M.S.E., Koudande, O.D. (2013): Grass-cutter breeding: an alternative for food security and wildlife safeguarding in West Africa. RASPA Vol.11 NOS, 113-128.

21. Mensah, G.A. et Ekué, M.R.M. (2003) : L'essentiel en aulacodiculture. ReRE, KIT,IUCN,CBDDBénin/ ISBN : 99919-102-4-0, $160 \mathrm{p}$.

22. Mensah, G.A. (1993): Futteraufnahme und verdaulichkeitbeingrasnager (Thryonomys swinderianus). Thèse de doctorat. Institut 480, Université de Holenheim, Allemagne, 107 p.

23. Mensah, G.A. (1995) : Consommation et digestibilité alimentaire chez l'aulacode (Thryonomys swinderianus). Trop, 13 (3) : 123-124.

24. Mensah, G.A. (2000) : Présentation générale de l'élevage d'aulacodes, historique et état de la diffusion en Afrique. Actes Séminaire international sur l'élevage intensif de gibier à but alimentaire à Libreville (Gabon), Projet DGEG/VSF/ADIE/CARPE/UE, pp.45-59.

25. Ngoula, F.F., Ajiahoung K., Defang Fualefac, H., Kenfack, A., Téguia A., and Tchoumboué, J. (2012): Effects of feed supplementation period on some reproductive parameters of female cane rats (Thryonomys swinderianus). Int. J. of Livest. Prod. vol. 3(7), pp. 78-82.

26. Nyameasem, J.K.(2010): Productive Performance and Carcass Characteristics of Captive Grasscutters (Thryonomys swinderianus) fed concentrate diets containing varying levels of Guinea Grass. Thesis Master of Science, Kwame Nkrumah University of Science and Technology, Kumasi, Ghana, 100p.

27. Okeke, J.J. \&Mogbo, T.C. (2013): Comparative stydy of growth performance of grasscutter fed on diverse foodstuff in captivity. I.J.A.B.R., 3(1) 2013: 85-89.

28. Okereke, C.O., Okereke, I.H., and Okiyi, P.C. (2015): Evaluation of the growth performance of grasscutter (Thryonomys swinderianus) fed diet containing varying levels of sweet potato rool meal and guinea grass (Panicum maximum). Nigerian Journal of Agriculture, Food and Environnement 11(3): 25-27.

29. Okuruwa, M.I., Esobhawan, A.O., Adomeh, E.E.,Ikheloa, E.E. (2014):Meat quality and Economic Analysis of Grasscutter (Thryonomys Swinderianus) fed mixture of Spear Grass and Sweet Potato Peels Supplemented with MoringaOleifera Leaves. International Journal of Applied Science and Technology, vol4, 우, 2014.

30. Omole, A.A.J., Ayodedeji, I.O., Ashaye, O.A. and Tiamiyu, A.K. (2005):Effect of Scalding and Flaming Methods of Processing on Physico-chemical and Organoleptic Properties of Grasscutter Meat. Journal of Applied Sciences Research 1(2): 249-252.

31. Poku Jnr, P.A., Annor, S.Y., and Djang-Fordjour, K.T. (2013): Growth, Reproduction and Carcass Characteristics of Grasscutters (Thryonomys swinderianus) Fed on Different Levels of Protein Supplement. World J. of Zool., 8(2): 175-184.

32. Pond, W.G., Church, D.C., and Pond, K.R. (1995): Basic Animal Nutrition and feeding (4 ${ }^{\text {th }}$ ed). John Wiley and Sons, Inc., New York.pp565-573.

33. R Core Team, (2012): R: A language and environment for statistical computing. R Foundation for Statistical Computing, Vienna, Austria.URL https://www.R-project.org/. 
34. Sacramento, T. I., Aïzoun, F. F.,Sinabaragui, O. S.,Mensah,G.A.,etAtegbo,J.M. (2013) : Détermination de l'âge de l'aulacode (Thryonomys swinderianus, Temminck 1827) femelle à partir des caractères morphométriques.Internationnal Journal of Biological and Chemical Sciences 7(4): 1427-1440, August 2013 ISSN 1991-8631.

35. Schrage, R. and Yewadan, T. (1999): Raising Grasscutters, Deutsche Gesellschaft fur TechnischeZusammenarbeit (GTZ) Gmbh, Eschbom, Germany, pp. 99.

36. Seidu, J.M.., Dzisi, K.A., Addo, A.G., Barte-Plange, A., Odai, B. (2016): Growth Performance of Grasscutters (Thryonomys swinderianus) in Captivity Fed on Pelleted Forage and Cassava Tubers with the Peel in Ghana. American Scientific Research Journal for Engineering, Technology, and Sciences, 2016, 18, №1, pp1-15.

37. Soro, S., Karamoko, Y., Soro, D., Gonnety, T.J., Fantodji, A. (2014): Contribution of young grass-cutter (Thryonomys swinderianus) feeding after weaning. Les Technologies de Laboratoire, $8: 34$.

38. Traoré, B., Fantodji, A., Allou V.K. (2008): Digestibility in vivo to the grasscutter(Thryonomys swinderianus). Arch. ZooteC. 57(218): 229-234.

39. Traoré, B., Fantodji, A., Mensah, G.A. (2009) : Influence of diets physical presentation on the growth and carcass yield ofThryonomys swinderianus in three physiological stages. Bul. Rec. Agr. Bénin, 65: 1-31.

40. Van Soest, P.J., Robertson J.B. and Lewis B.A. (1991): Methods for dietary fiber, neutral detergent fiber, and non-starch polysaccharides in relation to animal nutrition. J. of Dairy Sci, 74: 3583-3597.

41. Van Zyl, A., Meyer A.J. \&Merwe, V.M.(1999a).The influence of fibre in the diet on growth rates and digestibility of nutrients in the greater cane rat (Thryonomis swinderianus). Comparative Biochemistry and Physiology, Part A: Molecular and Integrative Physiology., 123(2): 129-135. http://dx.doi.org/10.1016/S10956433 (99) 00034-3.

42. Van Zyl, A., Merwe van der M., etBlignaut A.S. (1999b):Meat quality and carcass charactéristics of the vondo, Thryonomys swinderianus. S Afr J AnimSci 1999, 29(3).

43. WogarIkani, G.S. (2011): Performance of Growing Grasscutters (Thryonomys swinderianus) Fed CassavaBased Diets with Gradel Protein Levels. World J. Agri. Sci, 7(5): 510-514.

44. Wogar, G.S.I. (2012): Performance of Growing Grasscutters on Different Fibre Sources. Pak. J. Nutr. 11(1): 51-53.

45. Wogar, G.S.I. \&Ayuk A.A. (2012): By-Products as Protein Source for Lactating Grasscutters. J. Agri. Sci, 4(7); 2012.148-153.

46. Wogar, G.S.I. (2015): Growth and Reproductive Performance of Grasscutter Does with Litter Varying Levels of Cassava-based Energy Diet. J. Agri. Ecol. Res. Int, 4(1): 36-42.

47. Wogar, G.S.I., Ufot, M.L., Henry, A.J., Inyang I.E. \&Efe, E.E. (2013): Composition and Emulsifying Characteristics of Grasscutters Meat from Varying Dietary Levels. J. Agri. Sci, 5(1), 314-318.

48. Wogar, G.S.I. and Ayara, T.E. (2015): Performance of Growing Grasscutters fed a concentrate diet without supplementation. American Journal of Experimental Agriculture, 8(4): 253-260. 